\title{
A Microbiological Study of Acinetobacter calcoaceticus baumannii with Special Reference to Multidrug Resistance
}

\author{
Langamba Angom Longjam ${ }^{1}{ }^{10}$ Dechen Chomu Tsering ${ }^{1}$ Dipmala Das ${ }^{2}$
}

${ }^{1}$ Department of Microbiology, Sikkim Manipal Institute of Medical Sciences, Gangtok, Sikkim, India

Address for correspondence Langamba Angom Longjam, MSc, IQ

2 Department of Microbiology, IQ City Medical College and Hospital, City Medical College and Hospital, Sovapur, Bijra Road, Durgapur, Durgapur, West Bengal, India

West Bengal, 713206, India (e-mail: langom86@gmail.com).

J Lab Physicians 2022;14:169-174.

\section{Abstract \\ Keywords \\ - Acinetobacter calcoaceticus baumannii \\ - antibiotic susceptibility testing \\ - MDR strains \\ - Vitek2 compact system}

Introduction The outbreak of Acinetobacter calcoaceticus baumannii $(A C B)$ is mainly reported to be a notorious pathogens at health-care settings. It is the major problem on the health-care system with high morbidity and mortality rates because of the broad range of antibiotic resistance and lack of understanding the mechanism of developing new antibiotic resistance rapidly. It emphasizes the importance of local surveillance in describing or understanding and predicting microbial resistance patterns so that there will be limited use of antibiotics by developing strategies to control the extensive use of antimicrobial chemotherapy in clinical environment, which is still considered as one of the factors in the emergence of multidrug resistance microorganisms.

Objectives The study aims to detect the occurrence rate of $A C B$ infections from various clinical samples, identify the resistance levels to different groups of antimicrobial agents, and the occurrence rate of multidrug resistant (MDR) ACB clinical isolates from a tertiary hospital in Durgapur, West Bengal, India.

Material and Methods The study was performed in the Department of Microbiology of the IQ City Medical College and Hospital, Durgapur, West Bengal, India, for the 24 months duration, that is, from January 1, 2018 to December 31, 2019. Altogether 15,800 clinical samples consisting of endotracheal tube aspirates, sputum, pus, blood, catheter tips, urine, tissue, and other body fluids were studied. ACB from clinical samples were identified by its characteristic colonies (nonlactose fermenting, glistening, small mucoid colonies), Gram-staining pattern (Gram-negative coccobacillus), and standard biochemical reactions. It was further confirmed in the Department of Microbiology of the Healthworld Hospital, Durgapur, West Bengal, India, by Vitek2 compact system (bioMerieux, Inc., Durham, North Carolina, United States). Antibiotic susceptibility testing was performed using automated broth microdilutions by Vitek2 compact system (bioMerieux, Inc.) and Kirby-Bauer disk diffusion test on MuellerHinton Agar (HiMedia). published online

September 17, 2021
DOI https://doi.org/

10.1055/s-0041-1735583. ISSN 0974-2727. (c) 2021. The Indian Association of Laboratory Physicians. All rights reserved.

This is an open access article published by Thieme under the terms of the Creative Commons Attribution-NonDerivative-NonCommercial-License, permitting copying and reproduction so long as the original work is given appropriate credit. Contents may not be used for commercial purposes, or adapted, remixed, transformed or built upon. (https://creativecommons.org/ licenses/by-nc-nd/4.0/)

Thieme Medical and Scientific Publishers Pvt. Ltd., A-12, 2nd Floor, Sector 2, Noida-201301 UP, India 
Results Nonrepetitive $289 A C B$ were isolated from various clinical samples. A total of 277 (96\%) isolates of $A C B$ were MDR strains.

Conclusion $A C B$ was mostly isolated from the intensive care unit department and was found to be the most MDR type in the tertiary care hospital by this study.

\section{Introduction}

Acinetobacter calcoaceticus baumannii (ACB) are mainly reported to be the most important nosocomial pathogens at the intensive care units (ICUs) and health care settings housing very ill patients. ${ }^{1}$ Recent studies have reported its colonization at body sites such as the oropharyngeal wall, skin, and intestinal tract. ${ }^{2}$ About 8.3 to $41 \%$ of ICU patients are reported with colonization of intestinal tract. ${ }^{3}$ Various geographical areas have been reported for the outbreak of $A C B$, mainly Acinetobacter baumannii ${ }^{4}$ in which India has also been the forefront of such studies. Pan drug resistant $A$. baumannii isolates have been reported from Asia and the Middle East. ${ }^{5}$

The major alarm is the treatment of infections which are rapidly acquiring resistant to antibiotics. This includes extended spectrum $\beta$-lactamases to $\beta$-lactam and $\beta$-lactamase inhibitor, cephalosporins, and carbapenems. Furthermore, it has been linked to the loss or reduced expression of porins or overexpression of multidrug efflux pumps and mutations that change targets or cellular functions. ${ }^{6,7}$ Due to the emergence of carbapenem resistance in the strains of $A$. baumannii, largely through a clonal spread, the therapeutic options are decreasing. ${ }^{6,8,9}$ A. baumannii comes out to be an important agent of nosocomial infection in ICU patients associated with ventilator-acquired pneumonia, urinary tract infection, and other infections. ${ }^{10}$ Moreover, such type of infections are becoming more problematic due to the emergence of the multidrug resistant (MDR) strain. ${ }^{11-13}$ In a recent surveillance study in Greece, 3\% of $A$. baumannii strains derived from ICU patients were colistin resistant. ${ }^{14}$ The mortality rates varies from 7.8 to $75 \%{ }^{2}$ The MDR strain rarely occur outside of health care settings; however, community-acquired $A$. baumannii has been reported and progresses more rapidly with a higher mortality rate compared with hospital setting. ${ }^{11}$ Thus, it accentuates the importance of local surveillance in describing or understanding and predicting microbial resistance patterns so that there will be limit use of antibiotics by developing strategies to control on extensive use of antimicrobial chemotherapy in clinical environment which is still considered as one of the factors in the emergence of multidrug resistance microorganisms. The purpose of this study is to find out the occurrence rate of ACB infections from various clinical samples, identify the resistance levels to different antimicrobial agents and occurrence rate of MDR ACB clinical isolates from a tertiary hospital in Durgapur, West Bengal, India.

\section{Materials and Methods}

The study was performed in the Department of Microbiology of the IQ City Medical College and Hospital, Durgapur, West Bengal, India, for the 24 months duration, that is, from
January 1, 2018 to December 31, 2019. A total of 289 ACB nonrepetitive isolates from 15,800 clinical samples consisting of endotracheal tube aspirates, sputum, pus, blood, catheter tips, urine, tissue, and other body fluids were involved in the study. $A C B$ from clinical samples were identified by its characteristic colonies (nonlactose fermenting, glistening, small mucoid colonies), Gram-staining pattern (Gram-negative coccobacillus), and standard biochemical reactions. It was further confirmed in the Department of Microbiology of the Health World Hospital, Durgapur, West Bengal, India, by Vitek2 compact system (bioMerieux, Inc., Durham, North Carolina, United States). Antibiotic susceptibility testing was performed using automated broth microdilutions by Vitek2 compact system (bioMerieux, Inc.) and antibiotic disc diffusion test (Kirby-Bauer) according to the Central Laboratory Standards Institute (CLSI) interpretive criteria. ${ }^{15}$

For disc diffusion test, the antibiotic drugs with their concentration were piperacillin $(100 \mu \mathrm{g})$, piperacillintazobactam $(100 / 10 \mu \mathrm{g})$, ticarcillin-clavulanate $(75 / 10 \mu \mathrm{g})$, cefepime $(30 \mu \mathrm{g})$, ceftazidime $(30 \mu \mathrm{g})$, gentamicin $(10 \mu \mathrm{g})$, tobramycin $(10 \mu \mathrm{g})$, amikacin $(30 \mu \mathrm{g})$, doxycycline $(30 \mu \mathrm{g})$, tetracycline $(30 \mu \mathrm{g})$, ciprofloxacin $(5 \mu \mathrm{g})$, levofloxacin $(5 \mu \mathrm{g})$, trimethoprim-sulfamethoxazole or co-trimoxazole $(1.25 / 23.75 \mu \mathrm{g})$, meropenem $(10 \mu \mathrm{g})$, imipenem $(10 \mu \mathrm{g})$, and doripenem $(10 \mu \mathrm{g})$. These antibiotic discs were obtained commercially from HiMedia and BioRad distributors. Disk diffusion in colistin was not performed as broth microdilution is the only approved minimum inhibitory concentration test.

The disc diffusion test was performed on Mueller-Hinton Agar (HiMedia) as per the Kirby-Bauer method. Each zone size is interpreted according to the CLSI guideline and grouped as "susceptible (S), intermediate (I), and resistance (R)."

The resistance levels to different groups of antimicrobial agents were determined and the isolates were categorized as MDR, that is, resistance to one or more agents in at least three antimicrobial categories. ${ }^{11}$

\section{Results}

In our study, 289 nonrepetitive $A C B$ were isolated, which contributes $1.83 \%$ out of all the different 15,800 clinical samples. $A C B$ was most isolated from ICU, that is, 145 (50.17\%); followed by medicine ward, that is, 97 (33.56\%); surgical ward, that is, 32 (11.07\%), pediatric ward $13(4.50 \%)$; and cardiology $2(0.70 \%)$ as shown in - Table 1.

A total of 115 (39.79\%) of the $A C B$ isolates were from endotracheal tubes which were followed by sputum 63 (21.80\%), pus 62 (21.45\%), blood 34 (11.77\%), fluid 7 (2.42\%), urine $4(1.38 \%)$, other specimens like catheterized tips or tissue 3 (1\%), and throat swab $1(0.35 \%)$ as shown in - Table 2. 
Table 1 Distribution of isolation of Acinetobacter calcoaceticus baumannii $(N=289)$

\begin{tabular}{|l|l|l|}
\hline Wards or Units & Isolation & Percentage \\
\hline Intensive care unit (ICU) & 145 & 50.17 \\
\hline Medicine & 97 & 33.56 \\
\hline Surgery & 32 & 11.07 \\
\hline Pediatric & 13 & 4.50 \\
\hline Cardiology & 2 & 0.70 \\
\hline Total & 289 & 100 \\
\hline
\end{tabular}

Table 2 Clinical specimens showing isolation rates from different clinical samples

\begin{tabular}{|l|l|l|}
\hline Types of samples & $\begin{array}{l}\text { Isolates of } \\
\text { Acinetobacter } \\
\text { calcoaceticus } \\
\text { baumannii }\end{array}$ & Percentage \\
\hline Endotracheal secretions & 115 & 39.79 \\
\hline Sputum & 63 & 21.80 \\
\hline Pus & 62 & 21.45 \\
\hline Blood & 34 & 11.77 \\
\hline Fluid & 7 & 2.42 \\
\hline Urine & 4 & 1.38 \\
\hline Other specimens & 3 & 1 \\
\hline Throat swab & 1 & 0.35 \\
\hline Total & 289 & 100 \\
\hline
\end{tabular}

Among all the $A C B$ isolates, $88 \%$ were resistant to amikacin, $2 \%$ to tigecycline, and $96 \%$ to trimethoprim-sulfamethoxazole (co-trimoxazole). The other antibiotics like piperacillintazobactam, ticarcillin-clavulanate, cefepime, ceftazidime, gentamicin, levofloxacin, ciprofloxacin, meropenem, imipenem, and doripenem were $100 \%$ resistant as shown in - Table 3. All the isolates were sensitive to colistin and doxycycline antibiotics. Note that 277 (96\%) isolates of $A C B$ were MDR strains.

The data generated in the antibiotic susceptibility test given by the Kirby-Bauer disc diffusion test and automated microbroth dilution method as shown in - Table 3 was not so much variable, but they are qualitatively comparable to each other. The susceptibility pattern of piperacillin-tazobactam, ticarcillinclavulanate, ceftazidime, meropenem, imipenem, and doripenem showed similar pattern both in these two methods.

In the present study, a discordant result among the seven studied antibiotics was observed. The number of susceptible (S) isolates toward amikacin was more in the automated broth microdilution method, that is, $5 \%$ susceptible in disk diffusion and $12 \%$ susceptible in the automated broth microdilution method. However, the numbers of susceptible isolates were found to be decreased in the automated broth microdilution method, that is, cefepime, gentamicin, and levofloxacin showed 1,3 , and $4 \%$ higher susceptible in disk diffusion, respectively, as compared with the automated
Table 3 Comparison of antibiotic susceptibility pattern by Kirby-Bauer disk diffusion test and automated broth microdilution method

\begin{tabular}{|l|l|l|}
\hline $\begin{array}{l}\text { Name of } \\
\text { antibiotics }\end{array}$ & \% of Disk diffusion & of MIC \\
\hline $\begin{array}{l}\text { Piperacillin/ } \\
\text { Tazobactam }\end{array}$ & $\mathrm{S}=0, \mathrm{I}=0, \mathrm{R}=100$ & $\mathrm{~S}=0, \mathrm{I}=0, \mathrm{R}=100$ \\
\hline $\begin{array}{l}\text { Ticarcillin/ } \\
\text { Clavulanate }\end{array}$ & $\mathrm{S}=0, \mathrm{I}=0, \mathrm{R}=100$ & $\mathrm{~S}=0, \mathrm{I}=0, \mathrm{R}=100$ \\
\hline Ceftazidime & $\mathrm{S}=0, \mathrm{I}=0, \mathrm{R}=100$ & $\mathrm{~S}=0, \mathrm{I}=0, \mathrm{R}=100$ \\
\hline Cefepime & $\mathrm{S}=1, \mathrm{I}=1, \mathrm{R}=98$ & $\mathrm{~S}=0, \mathrm{I}=0, \mathrm{R}=100$ \\
\hline Amikacin & $\mathrm{S}=5, \mathrm{I}=7, \mathrm{R}=88$ & $\mathrm{~S}=12, \mathrm{I}=0, \mathrm{R}=88$ \\
\hline Gentamicin & $\mathrm{S}=3, \mathrm{I}=3, \mathrm{R}=94$ & $\mathrm{~S}=0, \mathrm{I}=0, \mathrm{R}=100$ \\
\hline Levofloxacin & $\mathrm{S}=4, \mathrm{I}=0, \mathrm{R}=96$ & $\mathrm{~S}=0, \mathrm{I}=0, \mathrm{R}=100$ \\
\hline Ciprofloxacin & $\mathrm{S}=4, \mathrm{I}=0, \mathrm{R}=96$ & $\mathrm{~S}=0, \mathrm{I}=0, \mathrm{R}=100$ \\
\hline Co-trimoxazole & $\mathrm{S}=4, \mathrm{I}=3, \mathrm{R}=93$ & $\mathrm{~S}=4, \mathrm{I}=0, \mathrm{R}=96$ \\
\hline Tigecycline & $\mathrm{S}=98, \mathrm{I}=0, \mathrm{R}=2$ & $\mathrm{~S}=97, \mathrm{I}=1, \mathrm{R}=2$ \\
\hline Doxycycline & $\mathrm{S}=100, \mathrm{I}=0, \mathrm{R}=0$ & Not applicable \\
\hline Meropenem & $\mathrm{S}=0, \mathrm{I}=0, \mathrm{R}=100$ & $\mathrm{~S}=0, \mathrm{I}=0, \mathrm{R}=100$ \\
\hline Imipenem & $\mathrm{S}=0, \mathrm{I}=0, \mathrm{R}=100$ & $\mathrm{~S}=0, \mathrm{I}=0, \mathrm{R}=100$ \\
\hline Doripenem & $\mathrm{S}=0, \mathrm{I}=0, \mathrm{R}=100$ & $\mathrm{~S}=0, \mathrm{I}=0, \mathrm{R}=100$ \\
\hline Colistin & $\mathrm{Not}$ applicable & $\mathrm{S}=100, \mathrm{I}=0, \mathrm{R}=0$ \\
\hline
\end{tabular}

Abbreviations: I, intermediate; MIC, minimum inhibitory concentration; $R$, resistant; S, sensitive.

a Doxycycline antibiotic is not available in the testing set of automated broth microdilution method.

${ }^{b}$ Colistin antibiotic is not recommended for disk diffusion test according to Central Laboratory Standards Institute (CLSI).

broth microdilution method. The numbers of resistance (R) isolates were mostly found in the automated broth microdilution method whereas there was no finding of intermediate (I) isolates. Both the data of antibiotic susceptibility has its associated advantages and disadvantages. The disc diffusion test is relatively easy to setup and inexpensive, but it does not provide quantitative data.

- Table 4 shows the percentage of resistant isolates particularly amikacin, co-trimoxazole, and tigecycline in the

Table 4 Distribution of resistant Acinetobacter calcoaceticus baumannii isolates particularly in amikacin, co-trimoxazole, and tigecycline in the different units of the hospital $(N=289)$

\begin{tabular}{|l|l|l|l|}
\hline $\begin{array}{l}\text { Wards or } \\
\text { Units }\end{array}$ & $\begin{array}{l}\text { Amikacin } \\
\text { No. of } \\
\text { resistant } \\
\text { isolates (\%) }\end{array}$ & $\begin{array}{l}\text { Co-trimoxazole } \\
\text { No. of resistant } \\
\text { isolates (\%) }\end{array}$ & $\begin{array}{l}\text { Tigecycline } \\
\text { No. of } \\
\text { resistant } \\
\text { isolates (\%) }\end{array}$ \\
\hline $\begin{array}{l}\text { Intensive } \\
\text { care unit } \\
\text { (ICU) }\end{array}$ & $145(100)$ & $145(100)$ & $6(4.13)$ \\
\hline Medicine & $73(75.25)$ & $95(97.93)$ & $0(0)$ \\
\hline Surgery & $32(100)$ & $30(93.75)$ & $0(0)$ \\
\hline Pediatric & $2(15.38)$ & $5(38.46)$ & $0(0)$ \\
\hline Cardiology & $2(100)$ & $2(100)$ & $0(0)$ \\
\hline
\end{tabular}


172 A Microbiological Study of $A C B$ with Reference to Multidrug Resistance Longjam et al.

Table 5 Distribution of resistant Acinetobacter calcoaceticus baumannii isolates in the various samples $(N=289)$

\begin{tabular}{|c|c|c|c|c|c|c|c|c|}
\hline Name of antibiotics & $\begin{array}{l}\text { Sputum } \\
\text { No. of } \\
\text { isolates } \\
(\%)\end{array}$ & $\begin{array}{l}\text { Urine } \\
\text { No. of } \\
\text { isolates } \\
\text { (\%) }\end{array}$ & $\begin{array}{l}\text { Blood } \\
\text { No. of } \\
\text { isolates } \\
\text { (\%) }\end{array}$ & $\begin{array}{l}\text { Endotracheal } \\
\text { tube (ET) } \\
\text { No. of } \\
\text { isolates (\%) }\end{array}$ & $\begin{array}{l}\text { Pus } \\
\text { No. of } \\
\text { isolates } \\
\text { (\%) }\end{array}$ & $\begin{array}{l}\text { Fluid } \\
\text { No. of } \\
\text { isolates } \\
\text { (\%) }\end{array}$ & $\begin{array}{l}\text { Other } \\
\text { specimens } \\
\text { like } \\
\text { catheterized } \\
\text { tips or tissue } \\
\text { No. of } \\
\text { isolates (\%) }\end{array}$ & $\begin{array}{l}\text { Throat } \\
\text { swab } \\
\text { No. of } \\
\text { isolates } \\
\text { (\%) }\end{array}$ \\
\hline \multicolumn{9}{|l|}{$\beta$-lactam combination agent } \\
\hline Piperacillin/Tazobactam & $\begin{array}{l}63 \\
(100) \\
\end{array}$ & $\begin{array}{l}4 \\
(100) \\
\end{array}$ & $\begin{array}{l}34 \\
(100) \\
\end{array}$ & $\begin{array}{l}115 \\
(100) \\
\end{array}$ & $\begin{array}{l}62 \\
(100) \\
\end{array}$ & $\begin{array}{l}7 \\
(100) \\
\end{array}$ & $\begin{array}{l}3 \\
(100) \\
\end{array}$ & $\begin{array}{l}1 \\
(100) \\
\end{array}$ \\
\hline Ticarcillin/Clavulanate & $\begin{array}{l}63 \\
(100)\end{array}$ & $\begin{array}{l}4 \\
(100)\end{array}$ & $\begin{array}{l}34 \\
(100)\end{array}$ & $\begin{array}{l}115 \\
(100)\end{array}$ & $\begin{array}{l}62 \\
(100)\end{array}$ & $\begin{array}{l}7 \\
(100)\end{array}$ & $\begin{array}{l}3 \\
(100)\end{array}$ & $\begin{array}{l}1 \\
(100)\end{array}$ \\
\hline \multicolumn{9}{|l|}{ Cephems (parenteral) } \\
\hline Ceftazidime & $\begin{array}{l}63 \\
(100) \\
\end{array}$ & $\begin{array}{l}4 \\
(100) \\
\end{array}$ & $\begin{array}{l}34 \\
(100) \\
\end{array}$ & $\begin{array}{l}115 \\
(100) \\
\end{array}$ & $\begin{array}{l}62 \\
(100) \\
\end{array}$ & $\begin{array}{l}7 \\
(100) \\
\end{array}$ & $\begin{array}{l}3 \\
(100) \\
\end{array}$ & $\begin{array}{l}1 \\
(100) \\
\end{array}$ \\
\hline Cefepime & $\begin{array}{l}63 \\
(100)\end{array}$ & $\begin{array}{l}4 \\
(100)\end{array}$ & $\begin{array}{l}34 \\
(100)\end{array}$ & $\begin{array}{l}115 \\
(100)\end{array}$ & $\begin{array}{l}62 \\
(100)\end{array}$ & $\begin{array}{l}7 \\
(100)\end{array}$ & $\begin{array}{l}3 \\
(100)\end{array}$ & $\begin{array}{l}1 \\
(100)\end{array}$ \\
\hline \multicolumn{9}{|l|}{ Carbapenems } \\
\hline Meropenem & $\begin{array}{l}63 \\
(100)\end{array}$ & $\begin{array}{l}4 \\
(100)\end{array}$ & $\begin{array}{l}34 \\
(100)\end{array}$ & $\begin{array}{l}115 \\
(100)\end{array}$ & $\begin{array}{l}62 \\
(100)\end{array}$ & $\begin{array}{l}7 \\
(100)\end{array}$ & $\begin{array}{l}3 \\
(100)\end{array}$ & $\begin{array}{l}1 \\
(100)\end{array}$ \\
\hline Imipenem & $\begin{array}{l}63 \\
(100)\end{array}$ & $\begin{array}{l}4 \\
(100)\end{array}$ & $\begin{array}{l}34 \\
(100)\end{array}$ & $\begin{array}{l}115 \\
(100)\end{array}$ & $\begin{array}{l}62 \\
(100)\end{array}$ & $\begin{array}{l}7 \\
(100)\end{array}$ & $\begin{array}{l}3 \\
(100)\end{array}$ & $\begin{array}{l}1 \\
(100)\end{array}$ \\
\hline Doripenem & $\begin{array}{l}63 \\
(100)\end{array}$ & $\begin{array}{l}4 \\
(100)\end{array}$ & $\begin{array}{l}34 \\
(100)\end{array}$ & $\begin{array}{l}115 \\
(100)\end{array}$ & $\begin{array}{l}62 \\
(100)\end{array}$ & $\begin{array}{l}7 \\
(100)\end{array}$ & $\begin{array}{l}3 \\
(100)\end{array}$ & $\begin{array}{l}1 \\
(100)\end{array}$ \\
\hline \multicolumn{9}{|l|}{ Aminoglycosides } \\
\hline Amikacin & $\begin{array}{l}49 \\
(77.8)\end{array}$ & $\begin{array}{l}4 \\
(100)\end{array}$ & $\begin{array}{l}25 \\
(73.52)\end{array}$ & $\begin{array}{l}113 \\
(98.26)\end{array}$ & $\begin{array}{l}52 \\
(83.87)\end{array}$ & $\begin{array}{l}7 \\
(100)\end{array}$ & $\begin{array}{l}3 \\
(100)\end{array}$ & $\begin{array}{l}1 \\
(100)\end{array}$ \\
\hline Gentamicin & $63(100)$ & $4(100)$ & $34(100)$ & $\begin{array}{l}115 \\
(100)\end{array}$ & $\begin{array}{l}62 \\
(100)\end{array}$ & $\begin{array}{l}7 \\
(100)\end{array}$ & $\begin{array}{l}3 \\
(100)\end{array}$ & $\begin{array}{l}1 \\
(100)\end{array}$ \\
\hline \multicolumn{9}{|l|}{ Tetracyclines } \\
\hline Tigecycline & $2(3.17)$ & $0(0)$ & $4(11.76)$ & $0(0)$ & $0(0)$ & $0(0)$ & $0(0)$ & $0(0)$ \\
\hline Minocycline & $0(0)$ & $0(0)$ & $0(0)$ & $0(0)$ & $0(0)$ & $0(0)$ & $0(0)$ & $0(0)$ \\
\hline \multicolumn{9}{|l|}{ Fluoroquinolones } \\
\hline Ciprofloxacin & $\begin{array}{l}63 \\
(100)\end{array}$ & $\begin{array}{l}4 \\
(100)\end{array}$ & $\begin{array}{l}34 \\
(100)\end{array}$ & $\begin{array}{l}115 \\
(100)\end{array}$ & $\begin{array}{l}62 \\
(100)\end{array}$ & $\begin{array}{l}7 \\
(100)\end{array}$ & $\begin{array}{l}3 \\
(100)\end{array}$ & $\begin{array}{l}1 \\
(100)\end{array}$ \\
\hline Levofloxacin & $\begin{array}{l}63 \\
(100)\end{array}$ & $\begin{array}{l}4 \\
(100)\end{array}$ & $\begin{array}{l}34 \\
(100)\end{array}$ & $\begin{array}{l}115 \\
(100)\end{array}$ & $\begin{array}{l}62 \\
(100)\end{array}$ & $\begin{array}{l}7 \\
(100)\end{array}$ & $\begin{array}{l}3 \\
(100)\end{array}$ & $\begin{array}{l}1 \\
(100)\end{array}$ \\
\hline \multicolumn{9}{|l|}{ Folate pathway antagonists } \\
\hline $\begin{array}{l}\text { Trimethoprim- } \\
\text { sulfamethoxazole } \\
\text { (co-trimoxazole) }\end{array}$ & $\begin{array}{l}56 \\
(88.88)\end{array}$ & $\begin{array}{l}4 \\
(100)\end{array}$ & $\begin{array}{l}34 \\
(100)\end{array}$ & $\begin{array}{l}115 \\
(100)\end{array}$ & $\begin{array}{l}57 \\
(91.93)\end{array}$ & $\begin{array}{l}7 \\
(100)\end{array}$ & $\begin{array}{l}3 \\
(100)\end{array}$ & $\begin{array}{l}1 \\
(100)\end{array}$ \\
\hline
\end{tabular}

different units of the hospital in which the ICU has got the highest resistant isolates, that is, 145 out of which $4.13 \%$ were resistant to tigecycline.

- Table 5 shows the distribution of resistant $A C B$ isolates in the various samples in which we found out that the resistant to amikacin were highly isolated from endotracheal specimen, that is, 113 (98.26\%), followed by 52 (83.87\%) isolates from pus, 49 (77.77\%) from sputum, and 25 (73.52\%) from blood specimen. Furthermore, the resistant to cotrimoxazole were highly isolated from pus and sputum, that is, 57 (91.93\%) and 56 (88.88\%), respectively. The tigecycline resistant isolates were isolated from blood specimen and sputum, that is, $4(11.76 \%)$ and $2(3.17 \%)$, respectively.

\section{Discussion}

Our study reveals that $A C B$ are commonly isolated from ICU (50.17\%). In the study done by Talukdar et al, ${ }^{16}$ the highest isolates $(51.41 \%)$ were from ICU, followed by the medicine ward (13\%) and surgical ward (11\%); pointing toward the fact 


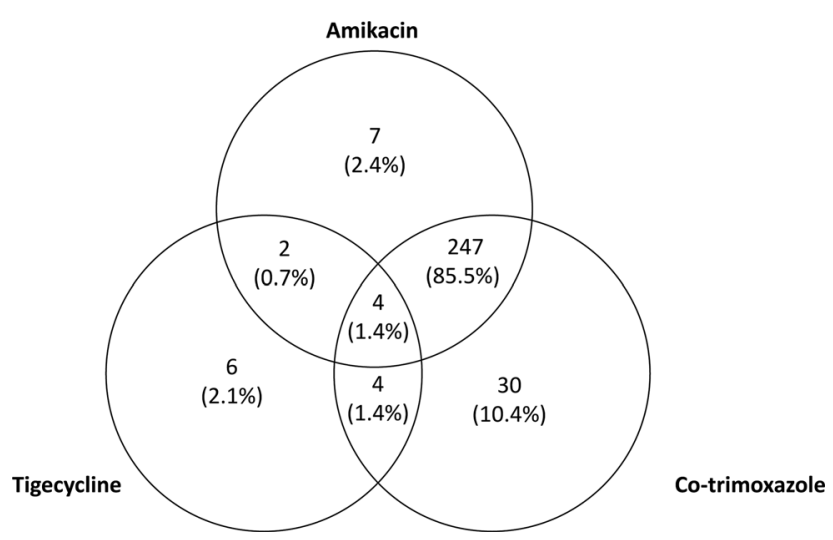

Fig. 1 Venn diagram showing association between three classes of antibiotics namely aminoglycosides (amikacin), folate pathway antagonists (co-trimoxazole), and tetracycline (tigecycline). Within the Venn diagram circles are 284 isolates representing varying degrees of antibiotic resistance (moderate resistance or fully resistant), while there are 5 isolates outside the Venn diagram, representing the susceptible isolates. Together, these constitute the entire population of Acinetobacter calcoaceticus baumannii complex isolates examined in this study (i.e., $N=284+5=289$ isolates).

that $A C B$ is a predominantly ICU bug. Our result substantiates the point that various risk factors are linked to ACB infection in ICU like chances of colonization among the sick and immune compromised patients. Those patients having multiple wounds, indwelling devices, and high antibiotic selective pressures are inclined for cross-transmission.

In our study, 277 (96\%) isolates of $A C B$ were reported as MDR strains with $100 \%$ resistance to most of the applied antibiotic except colistin and doxycycline. Banerjee et al showed reports of $88 \%$ MDR isolates with $100 \%$ resistance to most of the applied antibiotics except colistin and tigecycline. ${ }^{17,18}$ The promising available treatments for MDR strains are tigecycline or colistin. Unfortunately, our findings reveal $2 \%$ resistance among all isolates (289 in numbers) to tigecycline. In a recent surveillance study from Germany, tigecycline resistance among 215 A. baumannii was $6 \%{ }^{19}$ MDR ACB has associated with large morbidity and mortality after carbapenem-resistant Enterobacteriaceae and extended-spectrum beta-lactamase producing Enterobacteriaceae. ${ }^{20}$ With high antibiotic selective pressures, the MDR organisms acquire various antibiotic resistance mechanisms as a strategy for survival. In our present study, out of 145 isolates in the ICU ward, we found out 6 isolates, that is, $4.13 \%$, were resistant to tigecycline in the ICU as shown in - Table 4. Therefore, we assumed that the high use of tigecycline in managing the treatment of $A C B$ infection in ICU nowadays provide the emergence of tigecycline resistant strain in such environment although the relative contribution of these mechanisms are not yet known. Moreover, we highlighted firm application of antibiotic management program with strict hospital infection control measures to prevent nosocomial infection of MDR mostly in ICU. This study had limitations in aspect of number of isolates, short study period, and a single-center study. Therefore, a generalized finding with multicenter settings and long surveillance data has to be studied more especially molecular-based study.

\section{Conclusion}

MDR is being increasingly reported in $A C B$ and posing a threat to hospitalized patients due to the limitation of therapeutic options. This may be caused due to highly antibiotic selective pressure that we can easily see in the ICU environment. This is a significant burden on the health care system in excess costs due to an extensive treatment of symptoms and lack of understanding in how they persist.

\section{Source(s) of Support}

None.

\section{Authors' Contributions}

L.L.A.: Literature search, review of literature, manuscript preparation, concept and design of the study, data collection, statistically analyzed and interpreted, prepared first draft of manuscript, and critical review of study proposal. D.C.T.: Scientific advisor, critical review of study proposal, and helped in preparing first draft of manuscript.

D.D.: Scientific advisor, critical review of study proposal, and data collection.

\section{Conflict of Interest \\ None declared.}

\section{Acknowledgments}

We would sincerely thank Dr. Moushumi Lodh and Dr. Ashok Parida for their kindly cooperation and allowing help in conducting the research at the Healthworld Hospitals, Durgapur. And we would also like to thank Dr. Uma Shankar Saha for his support and supervision for analyzing the samples by Vitek2 compact system bioMerieux, Inc.

\section{References}

1 Centers for Disease Control. Overview of Drug-resistant Acinetobacter infections in healthcare settings. Centers for Disease Control and Prevention. Accessed February 18, 2017 at: www. cdc.gov/ncidod/dhqp/ar_acinetobacter.html

2 Manchanda V, Sanchaita S, Singh N. Multidrug resistant acinetobacter. J Glob Infect Dis 2010;2(03):291-304

3 Corbella X, Pujol M, Ayats J, et al. Relevance of digestive tract colonization in the epidemiology of nosocomial infections due to multiresistant Acinetobacter baumannii. Clin Infect Dis 1996;23 (02):329-334

4 Abbo A, Navon-Venezia S, Hammer-Muntz O, Krichali T, SiegmanIgra Y, Carmeli Y. Multidrug-resistant Acinetobacter baumannii. Emerg Infect Dis 2005;11(01):22-29

5 Hsueh P-R, Teng L-J, Chen C-Y, et al. Pandrug-resistant Acinetobacter baumannii causing nosocomial infections in a university hospital, Taiwan. Emerg Infect Dis 2002;8(08):827-832

6 Fernández-Cuenca F, Martínez-Martínez L, Conejo MC, Ayala JA, Perea EJ, Pascual A. Relationship between beta-lactamase production, outer membrane protein and penicillin-binding protein profiles on the activity of carbapenems against clinical isolates of Acinetobacter baumannii. J Antimicrob Chemother 2003;51 (03):565-574

7 Rice LB. Challenges in identifying new antimicrobial agents effective for treating infections with Acinetobacter baumannii 
174 A Microbiological Study of $A C B$ with Reference to Multidrug Resistance Longjam et al.

and Pseudomonas aeruginosa. Clin Infect Dis 2006;43(Suppl 2): S100-S105

8 Bergogne-Bérézin E. The increasing significance of outbreaks of Acinetobacter spp.: the need for control and new agents. J Hosp Infect 1995;30(Suppl):441-452

9 Go ES, Urban C, Burns J, et al. Clinical and molecular epidemiology of acinetobacter infections sensitive only to polymyxin B and sulbactam. Lancet 1994;344(8933):1329-1332

10 Dijkshoorn L, Nemec A, Seifert H. An increasing threat in hospitals: multidrug-resistant Acinetobacter baumannii. Nat Rev Microbiol 2007;5(12):939-951

11 Peleg AY, Seifert H, Paterson DL. Acinetobacter baumannii: emergence of a successful pathogen. Clin Microbiol Rev 2008;21(03): 538-582

12 Poirel L, Nordmann P. Carbapenem resistance in Acinetobacter baumannii: mechanisms and epidemiology. Clin Microbiol Infect 2006;12(09):826-836

13 Wareham DW, Bean DC, Khanna P, et al. Bloodstream infection due to Acinetobacter spp: epidemiology, risk factors and impact of multi-drug resistance. Eur J Clin Microbiol Infect Dis 2008;27 (07):607-612

14 Souli M, Kontopidou FV, Koratzanis E, et al. In vitro activity of tigecycline against multiple-drug-resistant, including panresistant, gram-negative and gram-positive clinical isolates from Greek hospitals. Antimicrob Agents Chemother 2006;50 (09):3166-3169

15 Clinical and Laboratory Standards Institute (CLSI). Performance Standards for Antimicrobial Susceptibility Testing (M100S). 28th ed. Wayne, PA: CLSI; 2018

16 Talukdar A, Hodiwala AB, Sharma R. Amicrobiological study of Acinetobacter baumannii with special reference to multi-drug resistance. Int J Curr Microbiol Appl Sci 2018;7(02):2319-7706

17 Khan ID, Basu A, Kiran S, Trivedi S, Pandit P, Chattoraj A. DeviceAssociated Healthcare-Associated Infections (DA-HAI) and the caveat of multiresistance in a multidisciplinary intensive care unit. Med J Armed Forces India 2017;73(03):222-231

18 Banerjee T, Mishra A, Das A, Sharma S, Barman H, Yadav G. High prevalence and endemicity of multidrug resistant Acinetobacter spp. in intensive care unit of a tertiary care hospital, Varanasi, India. J Pathogens 2018;2018:9129083

19 Seifert H, Stefanik D, Wisplinghoff $\mathrm{H}$. Comparative in vitro activities of tigecycline and 11 other antimicrobial agents against 215 epidemiologically defined multidrug-resistant Acinetobacter baumannii isolates. J Antimicrob Chemother 2006;58(05): 1099-1100

20 Mehrad B, Clark NM, Zhanel GG, Lynch JP III. Antimicrobial resistance in hospital-acquired Gram-negative bacterial infections. Chest 2015;147(05):1413-1421 